\title{
Clinic Evaluation of Heart Failure of Old People in the Department of Internal Medicine of Point G University Hospital from 2008 to 2012
}

\author{
Assétou Soukho Kaya1, Abdel Kader Traoré1, Djibril Sy¹, Djenebou Traoré1, Ilo Diall2, \\ Youssouf Fofana ${ }^{3}$, Ibahima Amadou Dembélé1, Boua Daoud Camara4, Mamadou Saliou', \\ Karim Dao1, Mamadou Cissoko', Kaly Kéïta1, Barry Boubacar Sangaré1, Mamadou Mallé1, \\ Alassane A. Doumbia1, Hadiza A. Kaïlou', Mamadou Dembélé1, Hamar Alassane Traoré1 \\ ${ }^{1}$ Department of Internal Medicine, Point G University Hospital, Bamako, Mali \\ ${ }^{2}$ Department of Cardiac Disease, Point G University Hospital, Bamako, Mali \\ ${ }^{3}$ Department of Internal Medicine of Children and Mothers, Le Luxembourg University Hospital, Bamako, Mali \\ ${ }^{4}$ Internal Medicine Service, Nianankoro Fomba Hospital, Ségou, Mali \\ Email: assetousouko@yahoo.fr,traoreak@gmail.com, hassiramadydembele@yahoo.fr,traorhamaralassane@yahoo.fr
}

How to cite this paper: Kaya, A.S., Traoré, A.K., Sy, D., Traoré, D., Diall, I., Fofana, Y., Dembélé, I.A., Camara, B.D., Saliou, M., Dao, K., Cissoko, M., Kéita, K., Sangaré, B.B., Mallé, M., Doumbia, A.A., Kaïlou, H.A., Dembélé, M. and Traoré, H.A. (2019) Clinic Evaluation of Heart Failure of Old People in the Department of Internal Medicine of Point G University Hospital from 2008 to 2012. Open Journal of Internal Medicine, 9, 83-88.

https://doi.org/10.4236/ojim.2019.93012

Received: June 26, 2019

Accepted: September 2, 2019

Published: September 5, 2019

Copyright $\odot 2019$ by author(s) and Scientific Research Publishing Inc. This work is licensed under the Creative Commons Attribution International License (CC BY 4.0).

http://creativecommons.org/licenses/by/4.0/

c) (i) Open Access

\begin{abstract}
Justification: Heart failure (HF) is the evolutionary end of all cardiac diseases. Given the aging population, the rate of incidence is increasing among the elderly. Objectives: The study aims to determine the prevalence of heart failure in the elderly; to describe the clinical aspects; describe etiologies; describe the therapeutic aspects; and describe the evolution of heart failure among the elderly. Method: This was a retrospective study over five years on the operating records of patients hospitalized in the internal medicine department of Hospital Point G. Result: The study included records of 22 elderly patients who were with heart failure of a total of 595 patients hospitalized from 1st January 2008 to 31st December 2012. The prevalence rate was 3.7\%, and the average age was $67 \pm 7.79$ years. The sex ratio was equal to 1 . HTA accounted for the cardiovascular risk factors in $77.3 \% .72 .7 \%$ of patients had the symptom of dyspnea and $95.5 \%$ of patients had the symptom of IMO. According to the cardiac ultrasound, dilation of the OG represented $68.2 \%$ of cases, followed by impaired LVEF (63.6\%). The etiologies of IC were represented by dilated cardiomyopathy (95.5\%), followed by $13.6 \%$ in cardiothyreosis. Drug treatment was dominated by the use of diuretics, ACE inhibitors and sodium diet respectively $95.5 \% ; 81.8 \%$ and $45.5 \%$ of cases. The clinical outcome was favorable in $73 \%$. We recorded four (4) cases of death, which accounted for $18 \%$ of patients.
\end{abstract}




\section{Keywords}

Heart Failure, Clinic, Etiology, Therapeutics, The Elder

\section{Introduction}

Heart failure usually with complex syndrome, is the final result of varies of advanced heart diseases.

In all situations, heart failure cannot maintain the cardiac output which body's metabolism needs. Heart failure is divided into left ventricular heart-failure, right ventricular heart-failure and whole heart failure [1] by the cavities arriving in specially or mainly.

Given the aging population, the prevalence is constantly increasing among the elderly [2].

In France, the number of patients of heart failure was predicted to be 500,000 in 1991, with 120,000 new cases every year. $2 / 3$ of them are patients over 75 years old [3].

Including 5000 patients who had been followed up for more than 40 years, the study of Framingham published in 1999 is the most important research in this domain. In this study, the prevalence of heart failure increased as the age increased, from $1 \%$ of 50 to 59 years of age to $9 \%$ of 80 -year-old people. The average of patients hospitalized due to heart failure in France was 76 years [4].

Heart failure was one of main causes of death and urgent hospitalization for people more than 65 years [5].

The prevalence of diastolic heart failure or remained ejection heart failure of people more than 75 years was $49.6 \%$ [6] [7].

In Mali, in the department of cardiology:

- According to the survey of Menta, the average age of patients with cardiovascular diseases was $68.8 \pm 0.3$ years old, and HTA as the main dangerous factor, accounted for $44 \%$, while tabagism accounted for only $2 \%$ [8].

- N'Guissan found the prevalence of heart failure with arrhythmia was $22.29 \%$ [1].

In the department of internal medicine of Point $G$ University regional central hospital, up to now, there wasn't a study for heart failure of the elderly who were objects of this work. The Target was to determine the prevalence of heart failure among the elderly and describe from the perspective of aspects of clinic, etiology, therapeutics, and evaluation of heart failure among the elderly.

\section{Patients and Method}

We carried a retrospective and descriptive in the department of internal medicine of Point G University central hospital, using cases of old patients, both male and female, from de data base of hospitalized from 1st January 2008 to 31st December 2012. 
All patients over 60 years during the time of survey who respect our criteria have been included after the acceptation of the ethic comity of the hospital.

The criteria of inclusion didn't include patients less than 60 years old with no heart failure, patients couldn't be tested by heart ultrasound and patients more than 60 years old without heart failure.

We collected detailed data of cases of all patients more than 60 years old, then entered these data into the personal survey sheet. For all patients, we collected variables of social demography (age, sex, ethnic group, profession and residence) shown in Table 1, clinical variables (general situation, weight and height, IMC calculation, dyspnea, pectoralgia, cough, palpitate, stress liver pain, lung spasm) that are shown in Table 2 and assistant clinical variables (echocardiogram, chest $\mathrm{X}$-ray, electrocardiogram, glucose, serum creatinine and ionogram of whole blood).

The entry and analysis of data were done on Épi info 3.5.3 software.

Table 1. Distribution by social demographic information $(n=595)$.

\begin{tabular}{ccc}
\hline Age & Frequency & Pourcentage \\
\hline $60-70$ Years Old & 410 & 68.91 \\
$<70$ Years Old & 185 & 31.09 \\
Average of Age & \multicolumn{2}{c}{$67 \pm 7.79$ Years Old } \\
Male & 244 & 41.01 \\
Female & 351 & 58.99 \\
Sex-Ratio & & 0.78 \\
Residence & Frequency & Pourcentage \\
\hline Urban Area & & $65 \%$ \\
Rural Area & & $35 \%$ \\
\hline
\end{tabular}

Table 2. Distribution by clinical information $(n=595)$.

\begin{tabular}{ccc}
\hline Clinical Variables & Frequency & Pourcentage \\
\hline Orthopnea & 297 & 49.9 \\
Obesity & 203 & 34.1 \\
Hypertension & 460 & 77.3 \\
Pectoralgia & 333 & 56 \\
Cough & 522 & 57.8 \\
Tachycardia & 324 & 54.5 \\
Hepatomegaly & 324 & 54.5 \\
swelling of jugular vein & 324 & 54.5 \\
Oedema & 568 & 95.5 \\
\hline
\end{tabular}




\section{Results}

From January 2008 to December 2012, 22 old patients matched inclusion criteria were recorded among 595 old patients with heart failure hospitalized in the department of internal medicine, and the frequency was $3.6 \%$.

The average age was $67 \pm 7.79$ years old. Housewives represented for $40.9 \%$ of these cases.

Patients having HTA accounted for $77.3 \%$. Tabagism was the dangerous factor of cardiovascular accounting for $22.7 \%$. Orthopnea was the sign of functional disorder, accounting for $49.9 \%$. Edema of lower extremity is the physical sign, accounting for $95.5 \%$, followed by hepatomegaly, tachycardia and swelling of jugular vein, each accounting for $54.5 \%$.

In the echocardiogram, $68.2 \%$ of patients had distention of the left atrium, followed by the change of ejection fraction, $63.6 \%$. The causes of heart failure included dilated cardiomyopathy, accounting for $95.5 \%$, followed by heart disease of hyperthyroidism (13.6\%). The ray X was not normal for $96.3 \%$ of patients. No patient was diabetic and we did not find any renal deficiency.

Drug treatment was dominated by the use of diuretics, ACE inhibitors and sodium diet respectively $95.5 \% ; 81.8 \%$ and $45.5 \%$ of cases.

The clinical outcome was favorable in $73 \%$. We recorded four (4) cases of death, which accounted for $18 \%$ of patients.

\section{Discussion}

Has all retrospective screening the limit of this study is that, the inclusion criteria do not cover all the patients because of the limitation of information. In our survey, HTA was the most common dangerous factor of cardiovascular, accounting for $77.3 \%$. This result was lower than result of survey of Menta's survey (44\%) [8] and result of survey of N'Guissan's survey (37.8\%) [1].

Among patients in our survey, patients having tabagism accounted for $22.7 \%$. This result was lower than result of survey of Menta, in which patients having tabagism accounted for $2 \%$ [8].

The main sign of functional disorder was dyspnea, accounting for $72.7 \%$ of these cases. Menta got a similar result-76\% [8].

Our result was lower than the result of survey of René which found dyspnea accounting for 91\% [9].

Cough accounted for $40.9 \%$ of cases in our survey. René found cough accounting for $77.7 \%$ [9].

It could be explained by the large number of samples, and so did our methods (ages of our patients were more than or equal to 60 years averagely).

Edema of lower extremity was the physical sign in $95.5 \%$ of our patients. René [9] found edema of lower extremity accounting for $77.1 \%$.

In cases of our survey, hepatomegaly accounted for $54.5 \%$. This result was lower than the result of René [9] whose result was 74.7\%. 
We have noticed that cardiomegaly had a large proportion in cases of our survey, accounting for $54.5 \%$.

Results of René [9], Ikama et al. [2] and Menta [8]'s survey about cardiomegaly were $92.6 \%, 97.3 \%$ and $77 \%$. The reason why percentage of results of these investigators was higher might be their large quantity of samples.

Electric left ventricular hypertrophia accounted for $31.8 \%$ among cases of our survey. This result was similar with result of survey of René [9] (37.2\%), but dissimilar against N'Guessan [1] (86.4\%).

Dilatation of left atrial often appeared in cases, accounting for $68.2 \%$. This result was same with result of N'Guissan [1] which recorded the proportion of dilatation of left atrial as $62.1 \%$. However, proportion of dilation of left atrial recorded by René [9] was on the low side, $33.6 \%$.

The change of ejection fraction was the abnormal phenomena tested by ultrasonic, accounting for $63.6 \%$ of cases, while $36.4 \%$ of patients of cases having a good contractile function. This result was similar with N'Guissan [1], the ejection fraction having changed accounting for $72.9 \%$, while not changed accounting for $27.1 \%$. But in the survey of René [9], patients whose ejection fraction didn't change were more than half.

Cause of heart failure was mainly dilated cardiomyopathy, accounting for 95.5\%. Considering $77.3 \%$ of patients having past histories of HTA, cardiomyopathy was possible to come from hypertension.

This result was higher than result of N'Guessan, the latter finding myocardiopaty accounting for $37.8 \%$, and primordial dilated cardiomyopathy [1] accounting for $32.5 \%$.

Among patients in our survey, people having heart disease of hyperthyroidation accounted for $13.6 \%$. René [9] recorded that heart disease of hyperthyroidation had a small proportion, $1.2 \%$.

In addition, study of N'Guessan [1] and Menta [8] didn't have heart failure of hyperthyroidation. This could be explained by place of study, and our study was carried out in the department of internal medicine.

There was no record of valvular heart disease or record of ischemic heart disease.

Using molecule mainly was diuretic, accounting for 95.6, IEC accounting for $81.8 \%$, followed closely by diet of low sodium, accounting for $45.5 \%$.

Our result was similar with René, who recorded diuretic (94\%) and IEC [9] (91.6\%) in order. But Menta [8] pointed out in his study that the usage of IEC was little, accounting for $18.5 \%$.

On the one hand the reason of this difference might be that the survey of Menta [8] had been a long time (1999), on the other hand it might become the change of loads for heart failure.

Evolution of $73 \%$ of patients was favorable. This result was similar with René [9], in which favorable change was $81.3 \%$.

We have recorded the death rate of $18 \%$. This also existed in the result of sur- 
vey of Menta I A [8], in which the death rate was $15 \%$, in the survey of René [9] $10.3 \%$, and in the review of Wernard [10] $13.8 \%$.

\section{Conclusions}

Heart failure often appeared among the elderly and had a serious prognosis. Because of the find in later stage and frequency of appearance of related pathology, it was difficult to diagnose positively.

Regular follow-up and good education are for a better treatment, and well responding to the treatment can guarantee the elderly to get a good life quality.

\section{Conflicts of Interest}

The authors declare no conflicts of interest regarding the publication of this paper.

\section{References}

[1] N'uissan, N. (2009) Insuffisance cardiaque et trouble du rythme supraventriculaire chez le sujet âgé. Faculté de Médecine de Pharmacie et d'Odonto-Stomatologie. Thèse, Med, Bamako, No. 588.

[2] Ikama, M.S., Kimbally-Kaky, G., Gombet, T., Ellenga-Mbolla, B.F., Dilou-Bassemouka, L., Mongo-Ngamani, S., Ekoba, J. and Nkoua, J.L. (2008) Insuffisance cardiaque du sujet âgé à Brazzaville: Aspects cliniques, étiologiques, et évolutifs. Med Trop, 68, 257-260.

[3] Jondeau, G. (2006) Insuffisance cardiaque et cardiomyopathies. Arch Mal CEEUR Vaiss, 2, 3-79.

[4] Rywik, S.L. (2000) Insuffisance cardiaque du sujet âgé: Etiologies. European Journal of Heart Failure, 2, 413-421. https://doi.org/10.1016/S1388-9842(00)00106-9

[5] Rodriguez, D. (2008) Insuffisance Cardiaque. Med Mal Metab, 2, S97-S99.

[6] Lye, M. (2000) Insuffisance Cardiaque Diastolique. European Journal of Heart Failure, 2, 133-136. https://doi.org/10.1016/S1388-9842(00)00068-4

[7] Larsson, B.L. (2010) Insuffisance Cardiaque Diastolique. Scandinavian Journal of Primary Health Care, 28, 172-178.

[8] Menta, I.A. (1999) Pathologie cardiovasculaire du sujet âgé: Socio-démographie, épidémiologie, clinique, traitement et évolution. Faculté de Médecine et d'OdontoStomatologie Thèse, Med, Bamako, No. 01.

[9] Dakouo, M.R. (2010) Insuffisance cardiaque du sujet âgé dans le service de cardiologie A du CHU du Point G: Epidémiologie, clinique, thérapeutique et évolution. Faculté de Médecine et d'Odonto-Stomatologie Thèse, Med, Bamako, No. 498.

[10] Gavid, W. (2008) Insuffisance cardiaque: Les particularites chez la personne agee. Rev Prat Medecine Generale, 22, 719-720. 